\title{
Filamentous Bacteria Identification by VIT Method
}

\author{
A. Abusam, F. Al-Salameen, A. Mydlarczyk, and M.-E. I. Ahmed
}

\begin{abstract}
Filamentous sludge bulking and foaming problems are common operational problems of activated sludge systems worldwide. The Kuwait Institute for Scientific Research (KISR) has recently conducted a study to identify the filamentous bacteria proliferating Kuwait activated sludge systems. Weekly grab samples were collected from Riqqa and Umm Al-Haiman activated sludge systems. To accurately identify the dominant filaments, a modern molecular biology technique was used, namely, Vermicon Identification Technology (VIT). Obtained results indicated that the dominant filamentous bacteria are: $\mathrm{N}$. limicola II, Type 1851, H. hydrossis and Nacordioform. Results of the assessment of systems' performance indicated that the Riqqa system was heavily impacted by the excessive growth of filamentous bacteria.
\end{abstract}

Index Terms-Activated sludge, bulking, foaming, effluent, quality.

\section{INTRODUCTION}

Activated sludge systems are used worldwide as wastewater secondary treatment systems. Filamentous sludge bulking and foaming problems are the most common operational problems of these systems [1]-[4]. If not properly controlled, excessive sludge bulking and foaming can lead to a complete failure of the entire wastewater treatment process [5].

Sludge bulking and foaming are often linked to a multitude of interrelated factors such as the influent quality, the plant operating variables and/or the environmental conditions [6]. In order to control the excessive growth of filamentous bacteria in activated sludge systems, considerable effort has been made worldwide to identify the dominant filamentous bacteria and the probable causes. This effort, however, is limited mainly to the temperate developed countries such as European countries, United States of America, South Africa and Japan [7]. In particular, little information is available about the filamentous bacteria growing in activated sludge systems of the countries located in tropical and desert climatic zones [8], [9].

Conventional methods of filamentous bacteria identification are based on the morphological characteristics of the filaments, which are unreliable [10]. Further, these

Manuscript received March 29, 2015; revised June 8, 2015. This work was supported in part by the Kuwait Foundation for the Advancement of Sciences under Grant 2012-1405-02.

Abdallah Abusam, Moh Elmuntaser Ahmed, and Andrzej Mydlarczyk are with the Water Research Center, Kuwait Institute for Scientific Research, Kuwait. P.O. Box 24885 Safat, 13109 Kuwait (e-mail: aabusam@kisr.edu.kw,_ miaahmed@kisr.edu.kw, amydlarczyk@kisr.edu.kw).

Fadeela Al-Salameen is with the Department of Biotechnology, the Environment \& Life Sciences Research Center, Kuwait Institute for Scientific Research, Kuwait. P.O. Box 24885 Safat, 13109 Kuwait (e-mail: fslamian@kisr.edu.kw). methods require laborious preparation of pure culture inoculums and lengthy microscopic characterization procedures. Molecular biology techniques, which have been developed in the last decades, have revolutionized the procedures of filamentous bacteria identification and tremendously increased the reliability of the identification results [11], [12]. To obtain accurate information about the filamentous bacteria proliferating Kuwait activated sludge systems, modern molecular biology techniques were used in this study.

\section{MATERIAL AND METHODS}

\section{A. Sample Collection and Handling}

$1000 \mathrm{ml} \mathrm{Grab}$ samples were collected weekly from the following four locations along Riqqa and Umm Al-Haiman activated sludge systems: the influent, the aeration tank, the secondary effluent and the tertiary effluent. All of the collected samples were place in sterile bottles. After in-situ measurement of temperature (Temp.), electrical conductivity (EC) and hydrogen ion concentrations $(\mathrm{pH})$, all of the samples were placed in an ice-box and transported for analysis with 24 $\mathrm{h}$ at the laboratories of Sulaibiya Research Plant (SRP) of Kuwait Institute for Scientific Research (KISR).

\section{B. Filaments Identification and Quantification}

The following Vermicon Identification Technology (VIT) kits were purchased from Vermicon Inc., Munich, Germany: VIT-1851, VIT-H. hydrossis, VIT-Nocardiaform, VIT-021N/Thiothrix, VIT-N. Limicola II and VIT-M parvicella. Identification and quantification of the dominant filaments were conducted within $24 \mathrm{~h}$ from the samples collection, according to Vermicon's instructions. All of the microscopic identifications and the quantification of the identified filaments were conducted independently by two observers.

Leica LS2 fluorescence microscope was used to investigate the presence and/or absence of filamentous bacteria. Images of the filaments were captured and visualized using Leica DFC295 digital colored camera system at standard resolution of $2048 \times 1536$ pixels ( 3 megapixels). The abundance of the identified filaments was then quantified using VIT proposed scoring scale which ranges from zero to five (0: None, 1 : few, 2: some, 3: many, 4: abundant and 5: excessive). To confirm the filament identification and abundance level, all of the microscopic investigations and scoring of identified filaments were conducted independently by two observers.

In order to confirm the filamentous bacteria found through VIT procedure, conventional identification was conducted based on classical taxonomy, morphology and biochemical tests. The streak plating method was used [13] was used for preparing pure culture, isolation of a desired microorganism. 
Morphological identification of the filamentous bacteria was achieved using the standard methods of gram staining as described by Skerman [14]. The motility of microorganism was observed in the wet mounts under the microscope, as a preliminary way to differentiate the bacterial types.

\section{Wastewater Quality Determination}

According to the standard methods used for water and wastewater examination APHA [15], the following 16 parameters were determined for wastewater samples collected from the influent, secondary and tertiary streams: Temperature (Temp.), $\mathrm{pH}$, electrical conductivity (EC), dissolved oxygen (DO), total suspended solids (TSS), volatile suspended solids (VSS), chemical oxygen demand (COD), five-days biochemical oxygen demand $\left(\mathrm{BOD}_{5}\right)$, volatile fatty acids (VFAs), oil and grease concentration (O\&G), Total Nitrogen $(\mathrm{TN})$, ammonia nitrogen $\left(\mathrm{NH}_{4}\right)$, nitrate nitrogen $\left(\mathrm{NO}_{3}\right)$, nitrite nitrogen $\left(\mathrm{NO}_{2}\right)$, total phosphorous (TP) and hydrogen sulfide $\left(\mathrm{H}_{2} \mathrm{~S}\right)$.

\section{RESULTS AND DISCUSSIONS}

\section{A. Dominant Filaments}

Fig. 1 presents the abundance of the identified filaments in samples collected from Riqqa aeration tank. This Figure shows that the filaments had started from almost nil (scale 0 or scale 1) in the first half of January 2014 and rapidly in only few weeks became abundant (scale 4) or even excessive (scale 5). Fig. 1 also shows that concentrations of Microthrix had the highest rate of fluctuations over time. This filament also seems to be adversely impacted by the sharp increase in water temperature during the hottest months (June, July and August) Fig. 2 shows that the same filaments were also dominant at Umm Al-Haiman system, with almost the same population dynamics as those found in Riqqa system. Interestingly, Microthrix had the same significant drop in population due to the sharp increase in water temperature during the summer season.

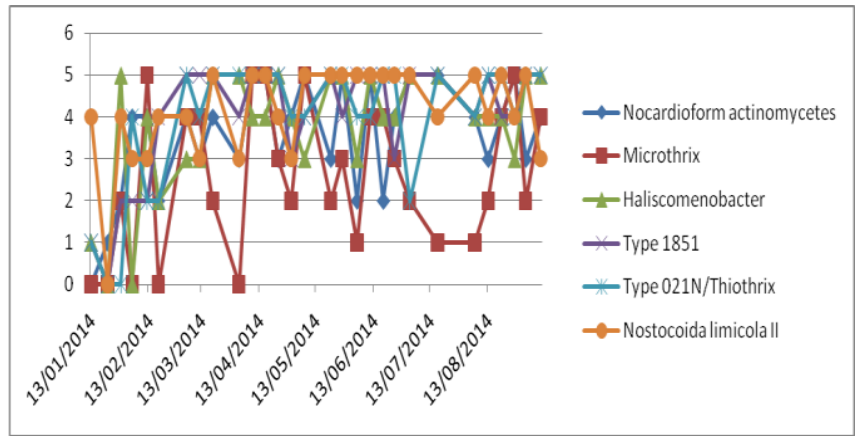

Fig. 1. Score of filamentous bacteria identified in Riqqa aeration tank.

As shown in Fig. 3, the descending ranking of the most dominant (> 70\% of time) filaments found in Riqqa aeration tank is as follows: N. limicola II, Type 1851, H. Hydrossis and Nacordioform. In general, the dominance of all filaments identified in Riqqa system was found to be higher during the summer season than that during the winter season (Fig. 4). Fig. 5 shows that the same filaments which were dominant in Riqqa aeration tank were also dominant in Umm Al-Haiman aeration tank. However, the ranking is slightly different (Fig.
6). Another significant difference is that the seasonal dominance of filaments. The dominance of the filaments during the summer season in Umm Al-Haiman system was relatively higher than that at Riqqa system, particularly for Nocardioform (Fig. 4 and Fig. 6).

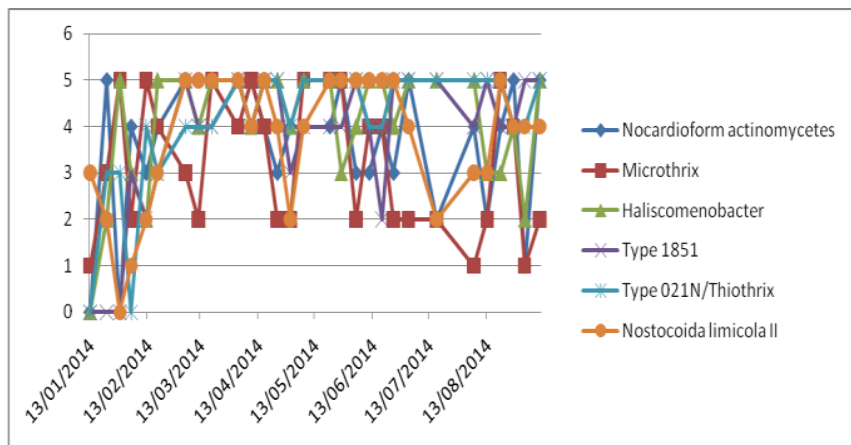

Fig. 2. Score of filamentous bacteria identified in Umm Al-Haiman aeration tank.

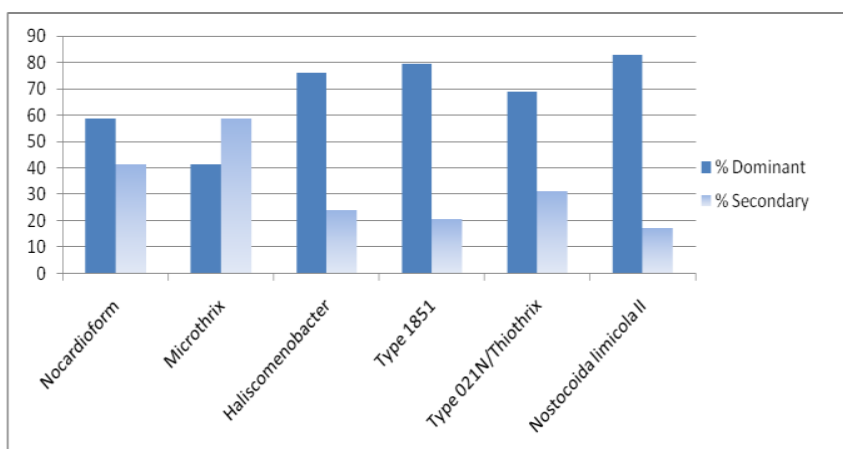

Fig. 3. Comparison of dominant and secondary filaments in Riqqa aeration tank during the whole sampling period.

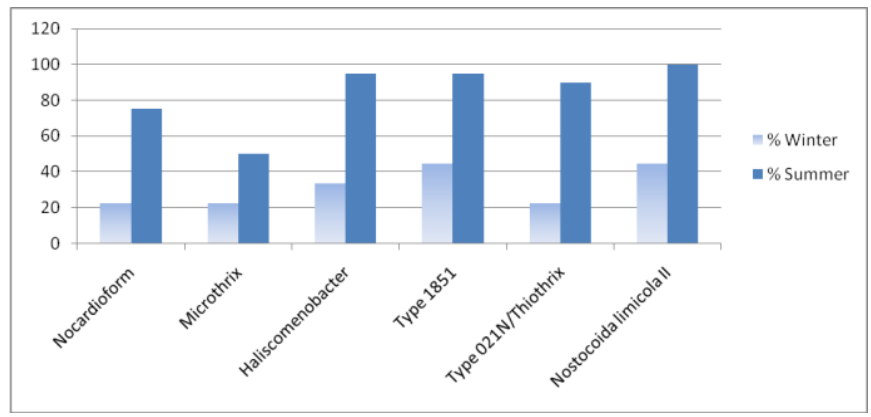

Fig. 4. Comparison of dominant filaments in Riqqa aeration tank during winter and summer seasons.

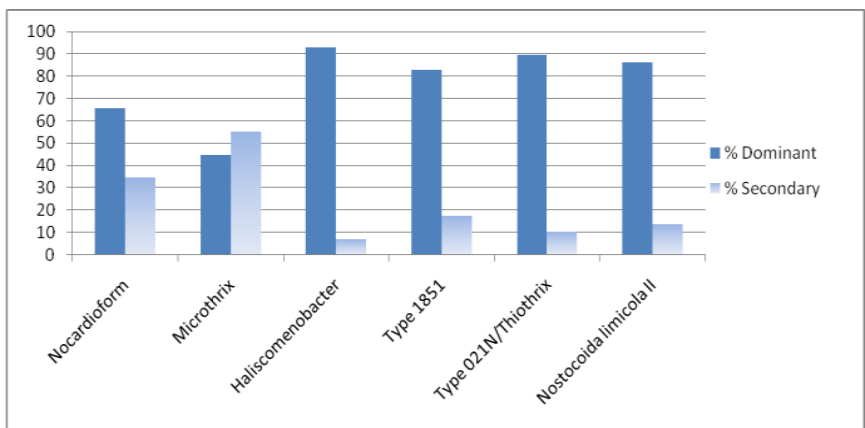

Fig. 5. Comparison of dominant and secondary filaments in Umm Al-Haiman aeration tank during the whole sampling period.

\section{B. Systems' Operation}

Riqqa activated sludge system is a conventional system which is design to treat $20,000 \mathrm{~m}^{3} / \mathrm{d}$, whereas Umm Al-Haiman activated sludge system is an oxidation ditch 
system design to treat $180,000 \mathrm{~m}^{3} / \mathrm{d}$. Table I shows that Riqqa activated sludge system was operated a very low DO (below $0.3 \mathrm{mg} / \mathrm{l})$, high OL and high F/M ratio. The high SVI during winter at Riqqa $(>350 \mathrm{ml} / \mathrm{g})$ indicates poor settleability of sludge due to sludge bulking. In contrast, Table II shows that Umm Al-Haiman system was operated at adequate DO and low organic loading (low OL and low F/M ratio), but at very high MLSS (> $7566 \mathrm{mg} / \mathrm{l})$. Although this strategy had resulted in less sludge bulking (SVI $<150 \mathrm{ml} / \mathrm{g}$ ), it definitely increased the aeration costs due the increase in the concentration of biomass. Since aeration is the major cost of activated sludge plants, this strategy has significantly increased the overall operational costs of Umm Al-Haiman plant.

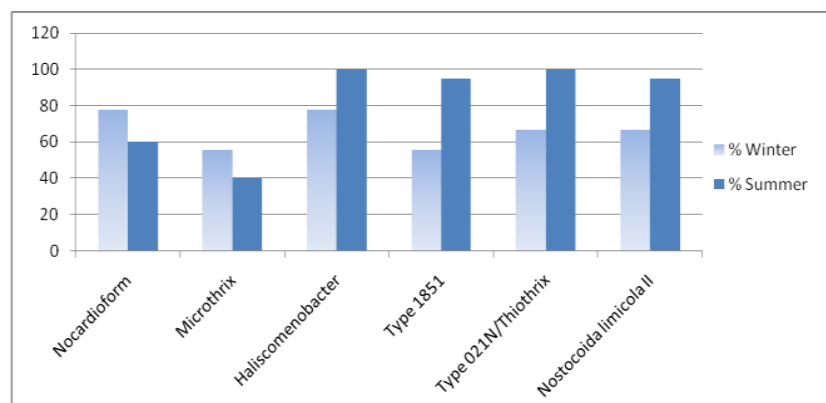

Fig. 6. Comparison of dominant filaments in Umm Al-Haiman aeration tank during winter and summer seasons.

TABLE I: OPERATION DATA OF RIQQA ACTIVATED SLUDGE SySTEM

\begin{tabular}{ccccccccc} 
Param. & \multicolumn{3}{c}{ Winter season } & \multicolumn{4}{c}{ Summer season } \\
& Min & Max & Mean & STD & Min & Max & Mean & STD \\
MLSS & 1850 & 2935 & 2564 & 326 & 2380 & 4445 & 3481 & 6493 \\
\hline SVI & 144 & 383 & 279 & 80.5 & 105 & 213 & 152 & 28.1 \\
DO & 0.06 & 0.26 & 0.13 & 0.07 & 0.03 & 0.65 & 0.29 & 0.06 \\
HRT & 10.1 & 13.4 & 12 & 0.87 & 11.3 & 16.4 & 13.8 & 10.1 \\
OL & 0.4 & 1.01 & 0.66 & 0.19 & 0.29 & 0.76 & 0.57 & 0.4 \\
F/M & 0.16 & 0.42 & 0.26 & 0.09 & 0.08 & 0.3 & 0.17 & 0.16
\end{tabular}

TABLE II: OPERATION DATA OF UMM AL-HAIMAN ACTIVATED SLUDGE SYSTEM

\begin{tabular}{ccccccccc} 
Param. & \multicolumn{3}{c}{ Winter season } & \multicolumn{4}{c}{ Summer season } \\
& Min & Max & Mean & STD & Min & Max & Mean & STD \\
\hline MLSS & 6735 & 8490 & 7566 & 627 & 5440 & 8335 & 7379 & 787 \\
SVI & 103 & 126 & 111 & 7 & 103 & 148 & 117 & 10 \\
DO & 0.23 & 4.1 & 1.86 & 1.28 & 0.38 & 2.31 & 1.54 & 0.62 \\
HRT & 29.8 & 42 & 34.9 & 4 & 26.1 & 42.9 & 32.8 & 5.1 \\
OL & 0.1 & 0.4 & 0.2 & 0.1 & 0.17 & 0.45 & 0.31 & 0.08 \\
F/M & 0.02 & 0.05 & 0.03 & 0.01 & 0.03 & 0.07 & 0.04 & 0.01
\end{tabular}

\section{Systems Performance}

Results of wastewater analysis (not shown here) indicated that there was no remarkable difference between the quality of the influent to the two plants, except the increase in VFAs concentrations in Riqqa influent from $29.2 \mathrm{mg} / \mathrm{l}$ during the summer season to $52.7 \mathrm{mg} / \mathrm{l}$ during the winter. However, Riqqa system was highly impacted by the excessive growth of filamentous bacteria. Both the secondary and tertiary effluents of this system were very poor, particularly during the winter season. In fact, the tertiary effluents of this system during winter did not meet KEPA standards for reuse of in agriculture ad landscape [16]. Averge TSS and BOD5 concentrations were higher than the standards. In contrast, Umm Al-Haiman system producing the almost the same high quality effluents and satisfied KEPA standards during both winter and summer seasons.

Filamentous sludge bulking and foaming are complex problems that are usually caused by many interrelated factors.
Therefore, it is recommended to conduct in the next step, a multivariate statistical analysis (e.g. principal component analysis) in order to associate the identified dominant filamentous bacteria to systems' design, operational and environmental conditions.

\section{CONCLUSIONS AND RECOMMENDATIONS}

- The filamentous bacteria dominating Riqqa and Umm Al-Haiman are: N. limicola II, Type 1851, H. hydrossis and Nacordioform.

- Riqqa system was highly affected by the over proliferation of filamentous bacteria, particularly during the winter season.

- It seemed that the adverse impacts of the excessive growth of filamentous bacteria in Umm Al-Haiman system was avoided through operating the system at a very high MLSS (> $7000 \mathrm{mg} / \mathrm{l}$ ).

- To pin-point to the probable causes of the problems, it is recommended to carry out a multivariate statistical analysis.

\section{REFERENCES}

[1] Met Calf and Eddy, Wastewater Engineering Treatment, Disposal, Reuse, $3^{\text {rd }}$ ed., New York, McGraw-Hill Publishing Company, Ltd., 2003.

[2] P. H. Nielsen, C. Kragelind, R. J. Seviour, and J. L. Nielsen, "Identity and ecophysiology of filamentous bacteria in activated sludge," FEMS Microbiology Reviews, vol. 33, no. 6, pp. 969-998, 2009.

[3] S. Posavac, T. L. Dragicevic, and M. Z. Hren, "The improvement of dairy wastewater efficiency by the addition of bio-activator," Mljekarstvo, vol. 60, no. 3, pp. 198-206, 2010.

[4] Z. Li, T. Zhang, N. Li, and X. Wang, "Granulation of filamentous microorganisms in sequencing batch reactor with saline wastewater," Journal of Environmental Sciences, vol. 22, no. 1, pp. 62-67, 2010.

[5] D. Soltysik, I. Bednarek, S. Galka, and D. Sypniewski, "Repetitive extragenic palindromic PCR (REP-PCR) as a method used for bulking process detection in activated sludge," Environmental Monitoring and Assessment, vol. 176, no. 1-4, pp. 343-354, 2011.

[6] H. Chua and K. Y. Le, "A survey of filaments foaming in activated sludge plants in Hong Kong," Water Science and Technology, vol. 30, no. 11 , pp. 251-254, 1994.

[7] T. Mino, "Survey on filamentous micro-organisms in activated sludge processes in Bangkok, Thailand," Water Science and Technology, vol. 31, no. 9, pp. 193-202, 1995.

[8] H. Safar and A. Abusam, "Preliminary investigations into causes of sludge bulking and foaming problems at Jahra activated sludge system," Kuwait Institute for Scientific Research, Report No. KISR 8758, Kuwait, 2007.

[9] S. M. Faheem and M. A. Khan, "A study on filamentous bacteria in activated sludge process of sewage treatment plant in Dubai, United Arab Emirates," Water Practice Technology, vol. 4, no. 2, pp. 1-8, 2009.

[10] A. T. Miekczrek, C. Kragelund, P. S. Eriksen, and H. P. Nielsen, "Population dynamics of filamentous bacteria in Danish wastewater treatment plants with nutrient removals," Water Research, vol. 46, no. 12, pp. 3781-3795, 2012.

[11] E. Fourest, D. Craperi, C. Deschamps-Roupert, J. L. Pisicchio, and G. Lenon, "Occurrence and control of filamentous bulking in treated wastewater treatment plants of the French paper industry," Water Science and Technology, vol. 50, no. 3, pp. 29-37, 2004.

[12] J. L. Sanz and T. Kochling, "Molecular biology techniques used in wastewater treatment - An overview," Process Biochemistry, vol. 42, pp. 119-113, 2007.

[13] J. G. Cappuccino and N. Sherman, Microbiology Laboratory Manual, 8th ed., San Francisco, CA, USA: Pearson/Benjamin Cummings, 2008.

[14] V. B. D. Skerman, A Guide to Identification of the Genera of Bacteria, $2^{\text {nd }}$ edition, Williams \& Wilkins, Baltimore, 1967. 
[15] APHA, Standard Methods for the Examination of Water and Wastewater, $21^{\text {st }}$ edition, American Public Health Association, Baltimore, Maryland, USA, 2012.

[16] A.-Y. Kuwait, Kuwait Al-Youm Newspaper, Annex to Issue 533, Year 47, 2001.

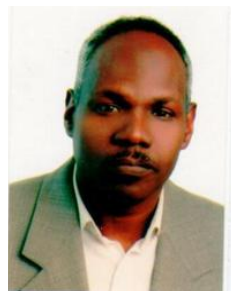

Abdallah Abusam was born in 1956 in Sudan. He has the B.Sc. hons in civil engineering from the University of Khartoum, Sudan, in 1982; the M.Sc. in sanitary engineering from the University of Khartoum, Sudan, in 1986; the MPH in environmental and occupational health sciences, from the University of Illinois at Chicago, USA, in 1990; and $\mathrm{PhD}$ in environmental engineering, from Wageningen University, the Netherlands 2001 .

$\mathrm{He}$ is a researcher and manager of the wastewater program at the Kuwait Institute for Scientific Research, Kuwait. He has published more 60 articles in conference proceedings and refereed journals.
Dr. Abusam is a fellow member of Sudanese Engineering Society. He is also a member of the Dutch Association for System and Control.

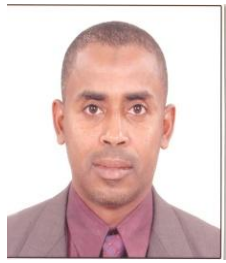

Mohamed-Elmuntasir Ibrahim Ahmed was born in Khartoum, Sudan and received the B.Sc. (honors) in civil engineering from the University of Khartoum, Khartoum, Sudan in 1992; the M.Ss. in civil engineering (environmental engineering) from Bradley University, Peoria, IL, USA in 1996, and $\mathrm{Ph} . \mathrm{D}$. in environmental engineering from Illinois 2000 . Institute of Technology (IIT), Chicago, IL, USA in

Currently, he is a research scientist at the Innovative Technologies for Wastewater Treatment and Reclamation (ITWTR) Program at Kuwait Institute for Scientific Research (KISR) in Kuwait. Dr Ahmed is a fellow of the Sudanese Engineering Society. 